\title{
Hydrodynamics in Holocene Lake Mega-Chad
}

\author{
Frédéric Bouchette ${ }^{\mathrm{a}, \mathrm{f}, *}$, Mathieu Schuster ${ }^{\mathrm{b}}$, Jean-François Ghienne ${ }^{\mathrm{c}}$, Cléa Denamiel ${ }^{\mathrm{d}}$, Claude Roquin ${ }^{\mathrm{c}}$, \\ Abderamane Moussa ${ }^{\mathrm{b}, \mathrm{c}}$, Patrick Marsaleix ${ }^{\mathrm{e}}$, Philippe Duringer ${ }^{\mathrm{c}}$ \\ a GEOSCIENCES-M, Université Montpellier II et CNRS, cc 60, Place Eugène Bataillon, 34095 Montpellier cedex 5, France \\ b Université de Poitiers UFR SFA, IPHEP - Institut International de Paléoprimatologie, Paléontologie Humaine: Evolution et Paléoenvironnements, CNRS UMR 6046, \\ 40 avenue du Recteur Pineau, 86022 Poitiers, France \\ ' Institut de Physique du Globe de Strasbourg (CNRS/Université de Strasbourg, UMR 7516, EOST), 1, rue Blessig, 67084 Strasbourg, France \\ ${ }^{\mathrm{d}}$ HR-Wallingford, Howbery Park, Wallingford, OX10 8BA, UK \\ e Laboratoire d'Aérologie-CNRS et Université de Toulouse, 14, Avenue Edouard Belin, 31400 Toulouse, France \\ ${ }^{\mathrm{f}}$ Institut de Mathématiques et modélisation de Montpellier, Université Montpellier II et CNRS, cc 51, Place Eugène Bataillon, 34095 Montpellier cedex 5, France
}

\begin{abstract}
Holocene Lake Mega-Chad (LMC) was the largest late Quaternary water-body in Africa. The development of this giant paleo-lake is related to a northward shift of the isohyetes interpreted as evidence for an enhanced Monsoon (African Humid Period). Numerous preserved coastal features have been described all around the LMC shore. Such features reveal the main paleo-hydrodynamical tendencies. In the context of a closed water-body like LMC, hydrodynamics are forced mainly by winds. We use a three-dimensional numerical model (SYMPHONIE) to simulate the mean hydrodynamics in LMC under both Harmattan-like (northeasterly trade winds) and Monsoon-like (southwesterly winds) forcings. The northern part of LMC displays coastal features, such as sand spits, that are consistent with the simulations forced by Harmattan-like winds. Geomorphic features related to Monsoon-driven hydrodynamics are not clearly expressed. They could have developed during the early stage of LMC but subsequently reworked. At the time of sandspit building, Harmattan-like driven hydrodynamics prevailed and related coastal features were preferentially preserved in the sedimentary record.
\end{abstract}

\section{Introduction}

One of the most striking facets of Holocene climate change in Africa is the occurrence of ancient lakes in the present-day Sahara desert (e.g., Maley, 1977; Damnati, 2000; Gasse, 2000). Paleolacustrine environments are represented either by mosaics of small lakes (e.g., in Mali: Petit-Maire and Riser, 1983) or by large water surfaces such as the Nubian Paleo-lake in Sudan $\left(>1000 \mathrm{~km}^{2}\right.$ ) (Pachur and Rottinger, 1997; Pachur and Hoelzmann, 2000), the northern Darfur Megalake in Sudan $\left(>30,000 \mathrm{~km}^{2}\right.$ ) (Ghoneim and El-Baz, 2007), or Lake Megafezzan in Libya $\left(>150,000 \mathrm{~km}^{2}\right.$ ) (Drake and Bristow, 2006; Armitage et al., 2007). Among all of them, Lake MegaChad (LMC) is the largest (Pias and Guichard, 1957, Schneider, 1967; Schuster et al., 2005) (Fig. 1). Its maximum surface area during the Holocene exceeded $350,000 \mathrm{~km}^{2}$ (Ghienne et al., 2002), which is comparable to the modern Caspian Sea. In the lakes occupying the southern Sahara, pollen proxies show that the hydrological conditions

\footnotetext{
* Corresponding author.

E-mail addresses: bouchette@gm.univ-montp2.fr (F. Bouchette), mathieu.schuster@univ-poitiers.fr (M. Schuster).
}

leading to the development of these water bodies were related to a northward shift of the isohyetes. This is interpreted as the expression of an enhanced Monsoon due to a precessionally driven increase of Northern Hemisphere insolation (deMenocal et al., 2000; Lézine et al., 2005), in agreement with paleo-climate simulations (Sepulchre et al., 2008).

Pre-Holocene large to giant lakes are also known, such as the late Pleistocene Shati Lake in Libya (Petit-Maire et al., 1980; Armitage et al., 2007), the Quaternary Ahnet-Moyer paleo-lake in Algeria (Conrad and Lappartient, 1991), and Miocene to Pliocene lake episodes in the Chad Basin (Schuster et al., 2001; Schuster, 2002). It is suggested that large lakes and associated hydrographic networks were recurrent geomorphic components of North African landscapes over the late Neogene. Sahara lakes also have conditioned terrestrial fauna dispersion, early hominid emergence and shifts in prehistoric settlements (Hoelzmann et al., 2001; Vignaud et al., 2002).

Schuster et al. (2005) identified and highlighted a number of coastal sedimentary paleo-systems distributed all around LMC, reflecting ancient wave-dominated conditions: these include waveinfluenced to wave-dominated deltas, beach ridges, sand spits and wave-cut terraces (Figs. 2 and 3). Resulting sedimentary architectures 


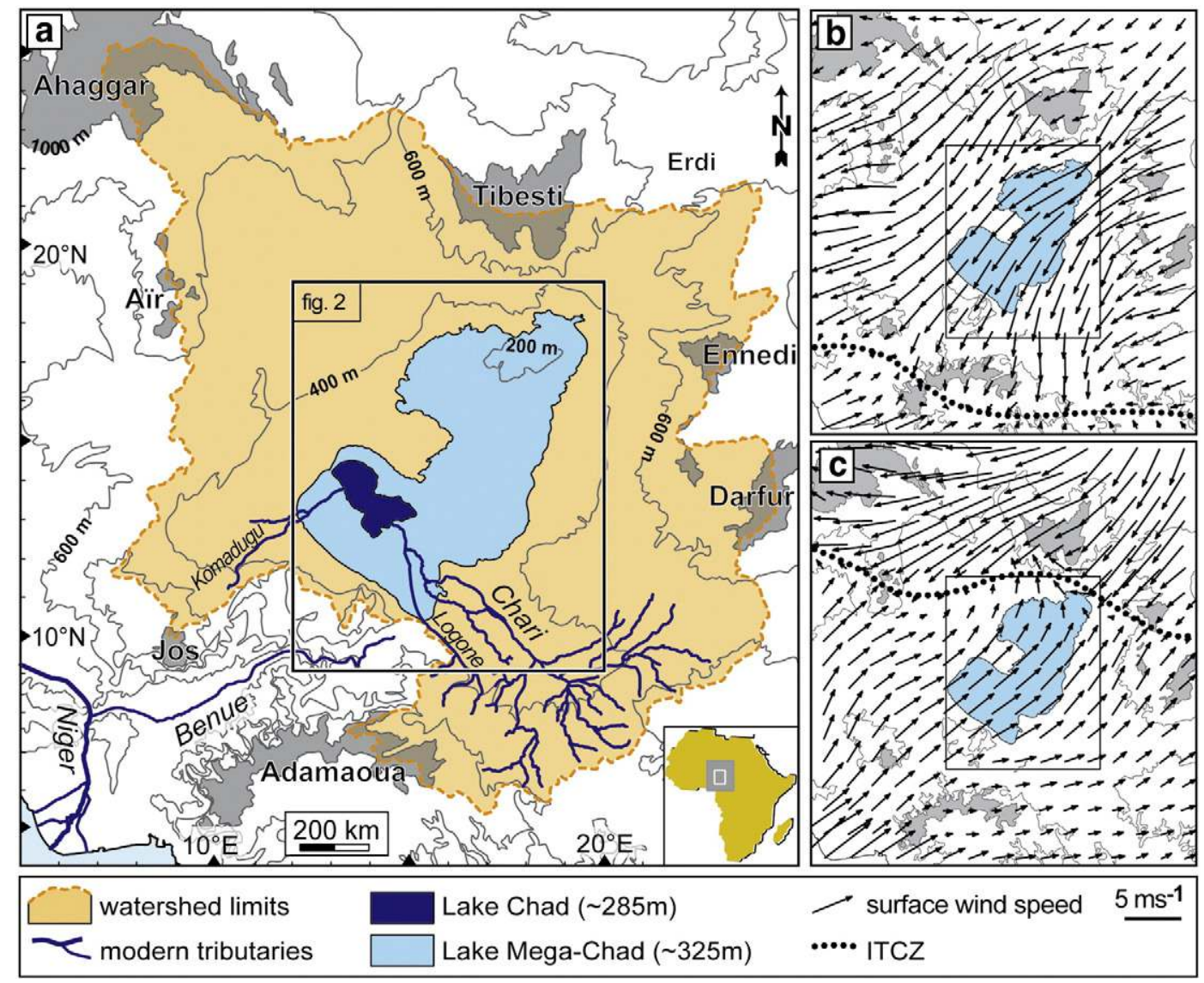

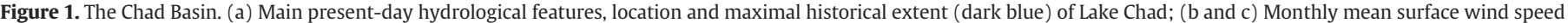
(1980-1992) for January (Harmattan) and August (Monsoon) respectively (modified from Engelstaedter et al., 2006).

may provide information about paleo-hydrodynamics and, especially, paleo-wind regimes (e.g., Krist and Schaetzl, 2001). In particular, Schuster et al. (2005) challenged the influence of Monsoon winds at the time of LMC development in this area otherwise dominated by northeasterly trade winds (i.e., Harmattan). This approach has been further developed by Drake and Bristow (2006), who concluded that the sedimentary geometries along the LMC shorelines resulted from the combination of seasonal shifts in wind direction with summer Monsoon-driven currents well recorded at the northern shorelines, in an area where the present-day Monsoon influence is very subordinate or absent. However, to interpret a wind regime from sedimentary architectures and derived alongshore drifts is not straightforward. In particular, several generations of coastal features have been noted that result in successive nested structures related to distinct LMC levels and/or events (Schuster et al., 2005). In this context, this study focuses on the youngest coastal features preserved in LMC

The objective of this study is to characterize the basin-scale morphodynamical behaviour based on the interpretation of numerical model results of wind-driven hydrodynamics. We apply a 3D numerical model (SYMPHONIE, Marsaleix et al., 2008) to simulate paleo-circulations in the LMC waterbody and to investigate relationships between wind forcing and water circulation, both at the air/ water interface and at the lake bottom. From numerical simulations we inferred trends in sediment drift that can be compared with identified sedimentary architectures, pointing out the influence of the inherited basin shape on the currents and the nearshore sediment budget. Finally, from this combined morphological and numerical approach, we discuss the prevailing wind forcing during the climatic optimum of the Holocene.

\section{The Chad Basin and the Holocene Lake Mega-Chad}

The Chad Basin is an intracratonic sag-basin located in North Central Africa (Burke, 1976; Hartley and Allen, 1994) (Fig. 1). The basement rocks of this basin are represented by crystalline rocks related to the Pan-African orogeny (ca. 750-550 Ma) (Kusnir and Moutaye, 1997). Above a Late Cretaceous to early Neogene cover, at least $500 \mathrm{~m}$ of Neogene lacustrine-dominated deposits occur in the centre of the basin. Several remarkable geomorphic units mark out the border of the basin, the extent of which is ca. $2.5 \times 10^{6} \mathrm{~km}^{2}$ (Wolf, 1964). To the North, Proterozoic basement overlain by Paleozoic strata and Cenozoic volcanic rocks of the Tibesti uplift represent the highest mountains in the Sahara (Emi Koussi, $3415 \mathrm{~m}$ ). To the northeast, the Cretaceous sandstones compose the plateau of the Erdi $(<800 \mathrm{~m})$. The eastern flank is bordered by the Paleozoic sandstones of the Ennedi Mountains $(<1450 \mathrm{~m})$ and the Proterozoic granitoid rocks of the Ouaddaï mountains $(<1100 \mathrm{~m})$. To the South, the lower outlet of the basin at an elevation of $c a .325 \mathrm{~m}$ is connected by the Mayo Kebi river to the Benue valley. This tectonically active area is related to the Cretaceous-Cenozoic rifting events affecting western and central Africa (Guiraud and Maurin, 1992). To the West, the late Pleistocene dune field of the Kanem (Servant and Servant-Vildary, 1980) constitutes a subdued topographic feature but the watershed limits of the Chad Basin reach the Jos Plateau (Nigeria, $<2010 \mathrm{~m}$ ) and Airr Moutains (Niger $(<2022 \mathrm{~m})$, respectively to the southwest and West (Fig. 1).

The current morphology of the Chad Basin is characterized by two separated sub-basins (Ghienne et al., 2002). The southern one corresponds to the hydrologic basin of the modern Lake Chad mainly fed by the Chari and Logone rivers (Fig. 2). The northern sub-basin 


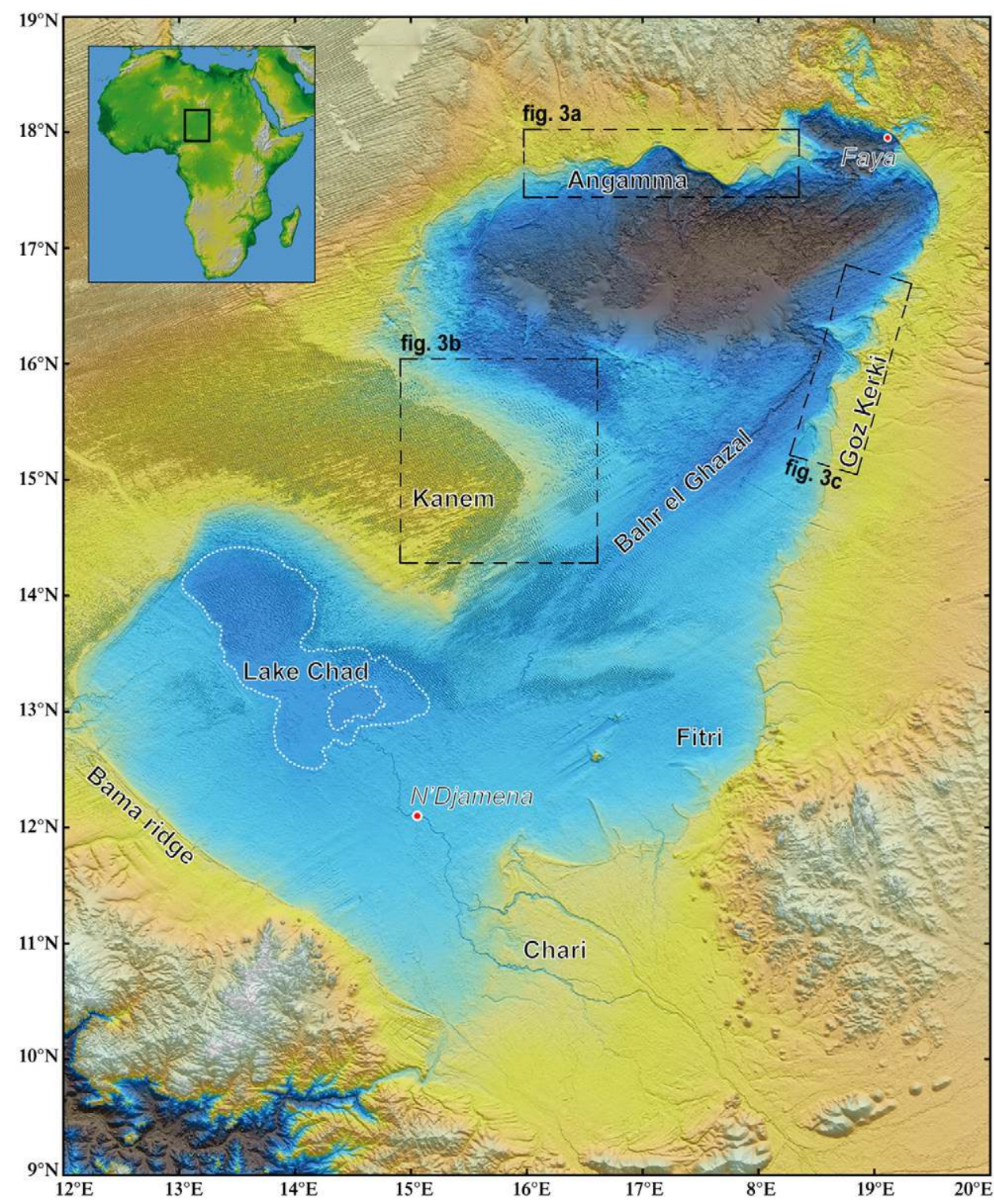

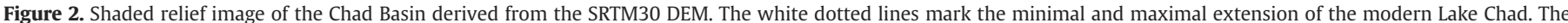

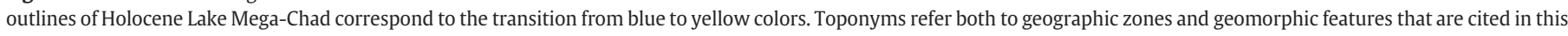
study.

corresponds to a low and large wind-deflated depression of less than $200 \mathrm{~m}$ in elevation (Mainguet and Chemin, 1990; Warren et al., 2007; Bristow et al., 2009). The modern lake level is currently varying between 275 and $280 \mathrm{~m}$ (Olivry et al., 1996). When water levels rise above $c a .285 \mathrm{~m}$, the southern sub-basin overflows and connects to the northern sub-basin via the present-day dry valley of the Bahr el Ghazal that has been occasionally flooded during historical times (Maley, 1981; Durand, 1995) (Fig. 2).

During the Holocene, a giant paleo-lake developed in the Chad Basin, ranging from $\mathrm{ca} .10^{\circ} \mathrm{N}$ to $18^{\circ} \mathrm{N}$ and from $12^{\circ} \mathrm{E}$ to $20^{\circ} \mathrm{E}$. Known as Lake Mega-Chad, it extended over more than $350,000 \mathrm{~km}^{2}$ and is therefore, by far, the largest Quaternary water-body of Africa (Ghienne et al., 2002; Schuster et al., 2005). With a maximum water level of ca. 320-325 m (Schuster et al., 2003), its water depth, derived from present-day topography, exceeded $150 \mathrm{~m}$ at its deepest part in the central northern sub-basin and was around $40 \mathrm{~m}$ in the area of the present-day Lake Chad.

Schuster et al. (2005) have highlighted many significant examples of ancient coastal geomorphic features (Fig. 2) that are distributed all around LMC, reflecting shoreline dynamics and sediment-input points (see also Drake and Bristow, 2006; Leblanc et al., 2006). To the South, the Chari-Logone drainage system draining wet tropical catchments resulted in a major delta system. Subordinate sediment supply was delivered at the Komadugu river mouth. To the East, numerous but less active drainage systems occurred as evidenced by series of small-scale paleodeltas distributed along the Goz Kerki spit system (Figs. 2 and 3c). Eolian sand supply essentially enters the Chad Basin through the Erdi Depression that connects the Libyan Desert and Western Desert of Egypt to the northeastern corner of the Chad Basin. To the North, coarse-grained sediments from rivers draining the Tibesti uplift fed a major fan-delta system known as the Angamma delta (Fig. 3a) (Ergenzinger, 1978). To the West, no significant river system occurred in an area essentially occupied by the late Pleistocene Kanem dune field (Servant and Servant-Vildary, 1980), along which wave-cut terraces have been identified (Schuster et al., 2005) (Fig. 3c). While shorelines were dominated by wave-reworked clastic sediments and shell accumulations (Schuster et al., 2005), sedimentation within this huge paleo-lake is represented by laminated silty clays and diatomite deposits preserved over an area of $c a .115,000 \mathrm{~km}^{2}$ (Kusnir and Moutaye, 1997). The coherence of shoreline geomorphic features with 

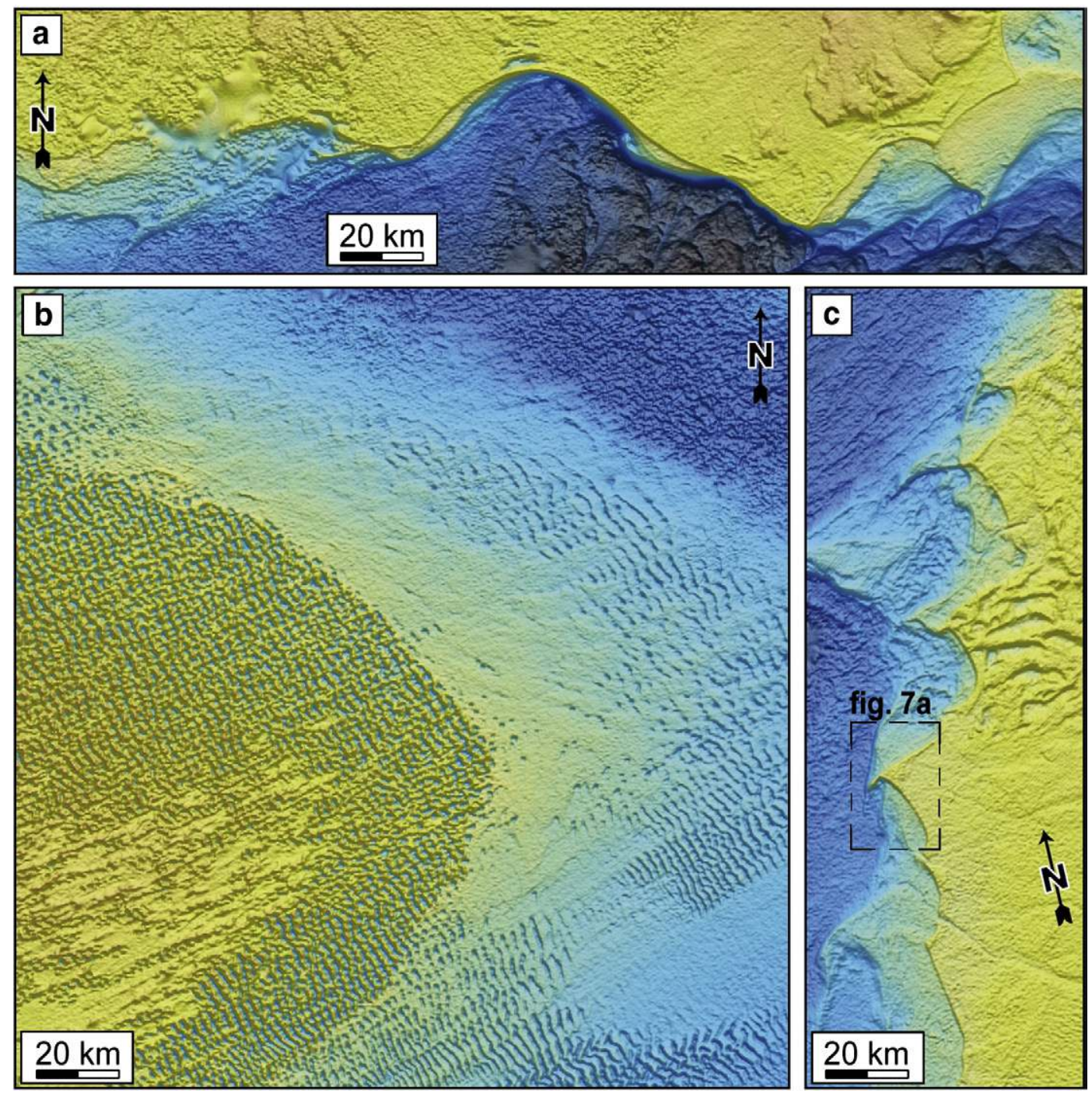

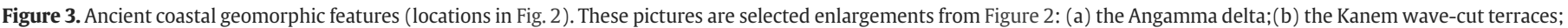
(c) the Goz Kerki spit system.

hydrodynamics will be assessed by numerical 3D simulations of wind forcings.

\section{The wind/buoyancy-forced model SYMPHONIE}

SYMPHONIE (Marsaleix et al., 2008) is an oceanographic tool dedicated to modelling coastal hydrodynamics. It is based on the Euler equations, with classical hydrostatic approximations and a free boundary at the air/water interface, like the models POM (Blumberg and Mellor, 1987) or ROMS (Shchepetkin and McWilliams, 2005). It computes the three-dimensional water circulation from wind forcing, fresh water supplies and buoyancy (resulting from water temperature and salinity gradients). It also includes a wave module that deals with the three-dimensional effects of the swell on the circulation (Mellor, 2003; Denamiel, 2006). SYMPHONIE uses sigma hybrid coordinates (so-called terrain-following coordinates) and computes currents at different vertical layers, including those at the air/water interface and at the bottom of the waterbody. In various operational case studies (Estournel et al., 2005; Denamiel, 2006; Ulses et al., 2008; Bouffard et al., 2008), SYMPHONIE reproduced well the currents measured with moored acoustic Doppler current profilers (ADCP or hull-mounted ADCP), even during storm events (Denamiel, 2006). Ulses et al. (2005) have shown that SYMPHONIE also successfully simulates the water circulation in a present-day semi-enclosed bay.
Waves generated by winds (wind waves) are taken into account by SYMPHONIE via the wind stresses at the air-water interface. In this study, the model was used to compute the water circulation forced by the Harmattan (northeasterly trade winds) and Monsoon (southwesterly wind). For these two opposite main wind azimuths, the longest fetches within each sub-basin were about $300 \mathrm{~km}$, resulting in wind waves and inferred currents that propagate in the whole LMC. In contrast with open sea case studies, deep water swell propagation over hundreds of kilometres was not introduced as a forcing term in SYMPHONIE to compute water circulation in the LMC. In addition, no fresh water supply was taken into account. Finally, possible water stratification was also neglected because the study focuses on the analysis of the nearshore zone where such phenomena are negligible to the first order of analysis.

Wind generates local wind waves through shear stress at the airwater interface, while swell observed at a specific location is derived from wind waves that have transformed and propagated away from a place where the wind blew. Both are waves that generate currents, induce cyclic shear stress at the bottom and create orbital motion in the water column. Both contribute to the shoreline dynamics. Bearing this in mind, it is obvious that the formation of coastal landforms such as sand spits requires the presence of waves (swell and/or wind waves) to remobilize sediment. The global shape and mean orientation of such geomorphic features result mainly from 
alongshore drift (Short, 1999). With alongshore drift being controlled by large-scale hydrodynamic processes such as wind-driven currents, SYMPHONIE then provided us with the relevant information to compare both the simulated and the observed orientations of coastal features.

\section{Model setting and selected simulations}

\section{Water depth and LMC coastlines}

The modelled water depth derives from the digital elevation model produced by the Shuttle Radar Topography Mission (SRTM; Rabus et al., 2003). The SRTM 30 data set corresponds to a DEM resolution of 30 arcseconds, equivalent to a cell size of about $900 \mathrm{~m}$ in width. The selected domain was interpolated (Akima, 1970; Wessel and Smith, 1998) and the domain modelled consists of a grid of 81 by 100 cells ( $6^{\prime}$ resolution, $c a .10 .8 \mathrm{~km}$ ) that take into account the driving topographic features while smoothing small-scale ones. Amongst the latter, the present-day eolian dunes were filtered. The water column was divided into 10 vertical layers from the air-water interface to the water-body bottom. Vertical terrain-following coordinates were used so that currents were computed in each cell about one meter below the water surface (irrespective of the water depth) and one meter above the water-body bottom. Between these two extremes, eight other computational layers were regularly distributed. A computation with terrain-following coordinates brings higher vertical resolution in the nearshore zone.

\section{Water elevation}

Distinct paleo-lake levels have been identified from the ancient morphodynamic features of the Chari and Angamma deltas, as well as from the Goz Kerki spit system and from the Kanem wave-cut terrace (Schuster et al., 2005). We processed four distinct paleo-water elevation models at $290 \mathrm{~m}, 300 \mathrm{~m}, 320 \mathrm{~m}$ and $330 \mathrm{~m}$. The last three cases correspond to connected southern and northern sub-basins with high water levels that allowed significant fetches and could have recorded global water circulation. At an elevation of $c a .290 \mathrm{~m}$, the lacustrine environment is represented by two separated water bodies of limited extension that could not have formed a steady hydrodynamic system. Therefore, in this case the hydrodynamics were not modelled.

\section{Other water attributes}

In the model, the surface water temperature is $16^{\circ} \mathrm{C}$, the salinity is that of fresh water and no rainfall was integrated. The mixing length at the lake bottom was set according to Blumberg and Mellor (1987).

\section{Wind azimuths and velocities}

Simulations have been performed with several wind pattern forcing (i.e., azimuth and velocity). A basic set of simulations involve uniform northeasterly (Harmattan-like) and southwesterly (Monsoon-like) winds at three different wind velocities $(5 \mathrm{~m} / \mathrm{s}$, $10 \mathrm{~m} / \mathrm{s}, 15 \mathrm{~m} / \mathrm{s}$ ) ranging from a fair-weather breeze to a storm condition. These values reflect the present-day range of both mean wind azimuth and velocity as inferred from two points in the Chad Basin (Fig. 2), one to the South (N'Djamena, Olivry et al., 1996), the other to the North (Faya, Capot-Rey, 1961; Mainguet and Chemin, 1990). The corresponding instantaneous maximal wind velocities, derived from these sustained wind forcings, may have varied from $7.5 \mathrm{~m} / \mathrm{s}$ to $22.5 \mathrm{~m} / \mathrm{s}$. The maximal value may convey possible increased wind conditions during the Holocene. Two additional and more realistic sets of simulations have been done: (i) a northeastward attenuation of southwesterly winds with no wind at the NE end of the lake surface that represents prevailing summer conditions; (ii) a southwestward attenuation coupled to a scattering of the azimuth of northeasterly winds that are representative of prevailing winter conditions. This latter peculiar field vector reflects the downstream spreading out of wind flows after their funnelling by the Ennedi-Tibesti mountains as shown by the orientation of ancient and modern wind erosion/deposition features (Mainguet and Chemin, 1990; Engelstaedter et al., 2006) (Figs. 1b and c).

\section{Quasi stationary hypothesis}

Each run represents a 24-h-long simulation that takes a few hours of computation on a $3 \mathrm{GHz}$ Pentium IV with $8 \mathrm{~Gb}$ of memory. Previous numerical studies have indicated that such durations lead to quasistationary flows in all cases, with no more change in generated current azimuths and a low increase of their velocities (Denamiel, 2006).

\section{Selected computations and relevant outputs}

The different computations processed are listed in Table 1. Given the uncertainty about early Holocene wind velocities, this study is not dedicated to a sharply exact quantification of the currents but is intended to illustrate the global distribution patterns at LMC scale. Having this in mind, a detailed examination of the results pointed out strong similarities between the computed hydrodynamics at water elevations of 300,320 and $330 \mathrm{~m}$ for each of the wind forcings. This examination also indicated that for a given wind azimuth, the variation of the wind speed does not shift significantly the location of the maximal and minimal values of the currents, nor their azimuths. Therefore, only the results for an elevation at $320 \mathrm{~m}$ are presented here. The forcings displayed are $10 \mathrm{~m} / \mathrm{s}$ for the Harmattan-like winds and $15 \mathrm{~m} / \mathrm{s}$ for Monsoon-like winds. Under these conditions, the main hydrodynamic features are well-expressed in the whole LMC and can be easily used for discussion.

Computed currents resulting from the three selected simulations are displayed as vector field and color scale maps of azimuths and intensities for both lake surface (Figs. 4a, 5a, 6a) and lake-bottom layers (Figs. 4b, 5b, 6b). The lake elevation is also displayed to illustrate the wind-induced surface tilt (downwind set-up and upwind set-down) (Figs. 4c, 5c, 6c). Finally, by combining these model outputs, we derived the relevant main hydrodynamic patterns of the water circulation in the LMC basin (Figs. 4d, 5d, 6d).

\section{Numerical results and main hydrodynamic features}

\section{Hydrodynamic conceptual background and assumptions for the} geological interpretation

The term "alongshore drift" refers to a mean mass transport of water and sediment oriented more or less alongshore (e.g., Fredsoe

Table 1

List of the various wind forcings used for the computation of the water circulation.

\begin{tabular}{llll}
\hline Paleo-Lake Chad water levels & 300m & $\mathbf{3 2 0 m}$ & $\mathbf{3 3 0 m}$ \\
\hline Harmattan at $5 \mathrm{~m} / \mathrm{s}$ & $\mathrm{X}$ & $\mathrm{X}$ & $\mathrm{X}$ \\
Harmattan at $10 \mathrm{~m} / \mathrm{s}$ & $\mathrm{X}$ & $\mathrm{X}$ & $\mathrm{X}$ \\
Harmattan at $15 \mathrm{~m} / \mathrm{s}$ & $\mathrm{X}$ & $\mathrm{X}$ & $\mathrm{X}$ \\
Monsoon at $10 \mathrm{~m} / \mathrm{s}$ & $\mathrm{X}$ & $\mathrm{X}$ & $\mathrm{X}$ \\
Monsoon at $15 \mathrm{~m} / \mathrm{s}$ & $\mathrm{X}$ & $\mathrm{X}$ & $\mathrm{X}$ \\
Monsoon at $15 \mathrm{~m} / \mathrm{s}$ with north-eastern attenuation & $\mathrm{X}$ & $\mathrm{X}$ & $\mathrm{X}$ \\
Harmattan at $10 \mathrm{~m} / \mathrm{s}$ with scattering of wind azimuths & & $\mathrm{X}$ & \\
\hline
\end{tabular}

The wind velocities mentioned refer to permanent wind forcings. If not mentioned, the forcing is constant over the whole modelled zone. The forcing with an attenuated Monsoon refers to a peculiar case where the wind dropped from $15 \mathrm{~m} / \mathrm{s}$ in the SW to zero in the NE. The " $\mathrm{X}$ " refers to case studies that were modelled and compared. The grey ones refer to case studies illustrated in this paper (Figs. 4-6). 

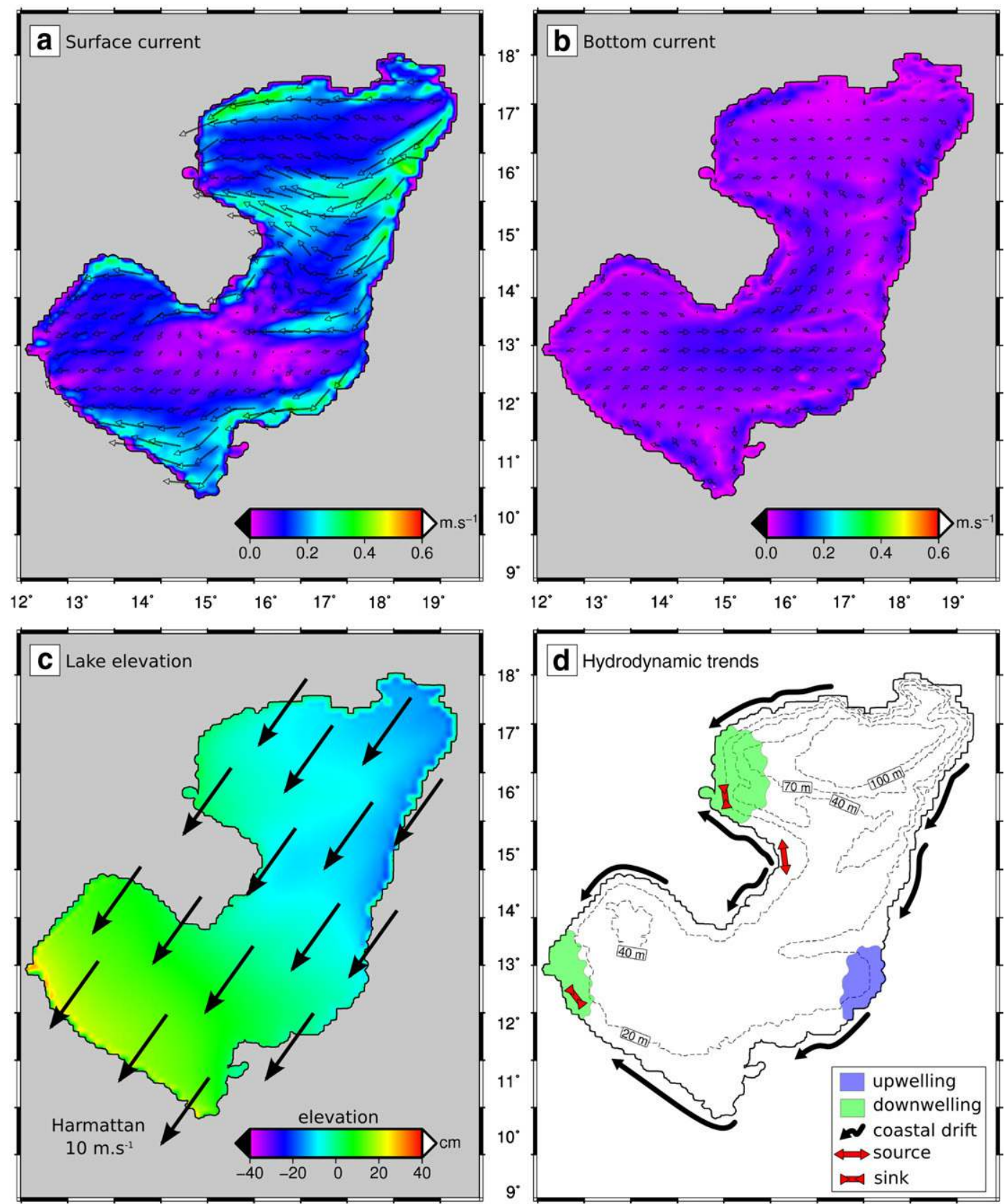

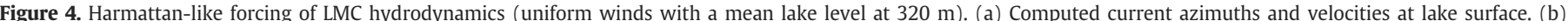

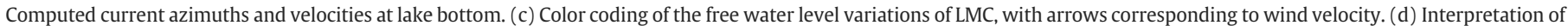
the hydrodynamic patterns.

and Deigaard, 1995; Short, 1999). In this paper, numerical simulations provide water circulation from which possible sediment transfer patterns can be inferred. Three different cases can occur. First, the surface current is oriented strictly along the shoreline: a bottom current displays the same azimuth and the mass transport is alongshore, with an azimuth consistent with surface and bottom currents. Second, the surface current is partly oriented lakeward: a bottom current oblique to, but oriented towards, the shoreline occurs and counterbalances this loss of water mass (upwelling). The alongshore drift azimuth is consistent with that of the surface current projected along the shoreline. Last, the surface current is partly oriented shoreward: a bottom current oriented basinward and oblique to the shoreline may occur (downwelling). In this case, the alongshore drift azimuth is still consistent with that of the surface current projected along the shoreline.
The term "source" is defined as a shoreface located at the divergence of two alongshore drifts. There, sediment exportation occurs. In this paper, the term source does not refer to an external sediment input point in the lake, such as a river mouth. The long-term evolution of such areas results in a negative sediment budget. The term "sink" refers to a shoreface that corresponds to the focal point of two convergent alongshore drifts, where sand accumulation usually occurs. The long-term evolution of such area results in a positive sediment budget. Consequently, on a geological time scale, a sink will favour beach accretion and formation of prograding sets while a source will limit both.

In addition to alongshore drifts, cross-shore transfers are forced by waves. Storm waves and fair-weather waves contribute differently to the reworking and the distribution of the sand along the shoreface profile. Usually, fair-weather waves produce well-expressed 

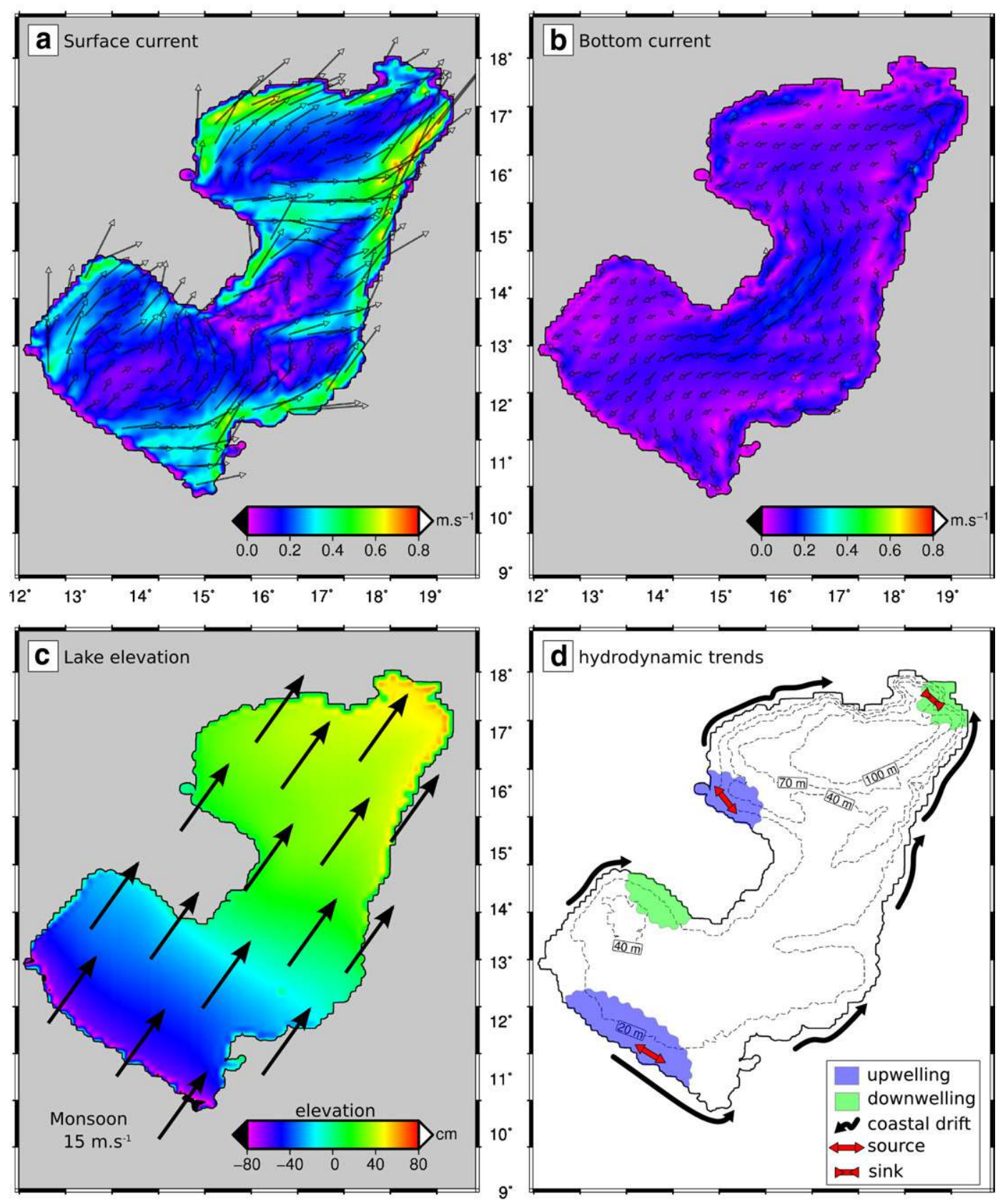

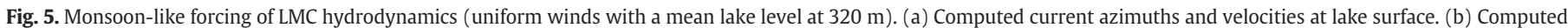

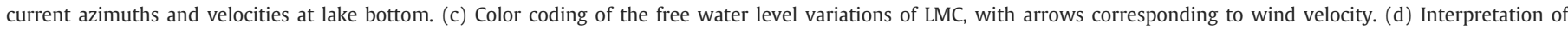
hydrodynamic patterns.

submerged sand bars that gradually translate shoreward (e.g., Short, 1999). Storm waves erode these sedimentary features and spread the sand basinward. These quasi-instantaneous processes (a few hours to a couple of days) strongly control the shape of the bottom profile but do not modify the sediment budget significantly at the shoreface scale. However, net basinward loss of sand may be observed during extreme storm events. If such events are frequent, they should be recorded in deposits lakeward, below the usual storm wave base, as a result of the decrease of the shoreface sedimentary budget.

In the LMC case study, the sandy shoreface width is about $1 \mathrm{~km}$. Lakeward, observed sediments essentially comprise silty clays and diatomite deposits. This clearly indicates that sand fluxes are limited to the nearshore zone and the cross-shore transfer of sand away from the coastline is negligible at a geological time scale. Finally, the long- term evolution of the sediment budget is controlled by alongshore fluxes.

This framework was used to interpret the hydrodynamic results in terms of morphodynamics. Figures 4-6 display the more significant features of the hydrodynamics at the LMC scale, where they were compared to the paleo-shoreline sedimentary features already described in previous papers and field observations.

\section{Northeasterly wind forcing (Harmattan-like)}

Figure 4 displays the results for a Harmattan wind forcing of $10 \mathrm{~m} / \mathrm{s}$. The results with a wind velocity of $15 \mathrm{~m} / \mathrm{s}$ display the same features, with the induced current velocities slightly increased (e.g., along the eastern boundary of the paleo-lake, mean velocities may locally reach $0.7 \mathrm{~m} / \mathrm{s}$ for a wind forcing of $10 \mathrm{~m} / \mathrm{s}$, and $1.2 \mathrm{~m} / \mathrm{s}$ for a 

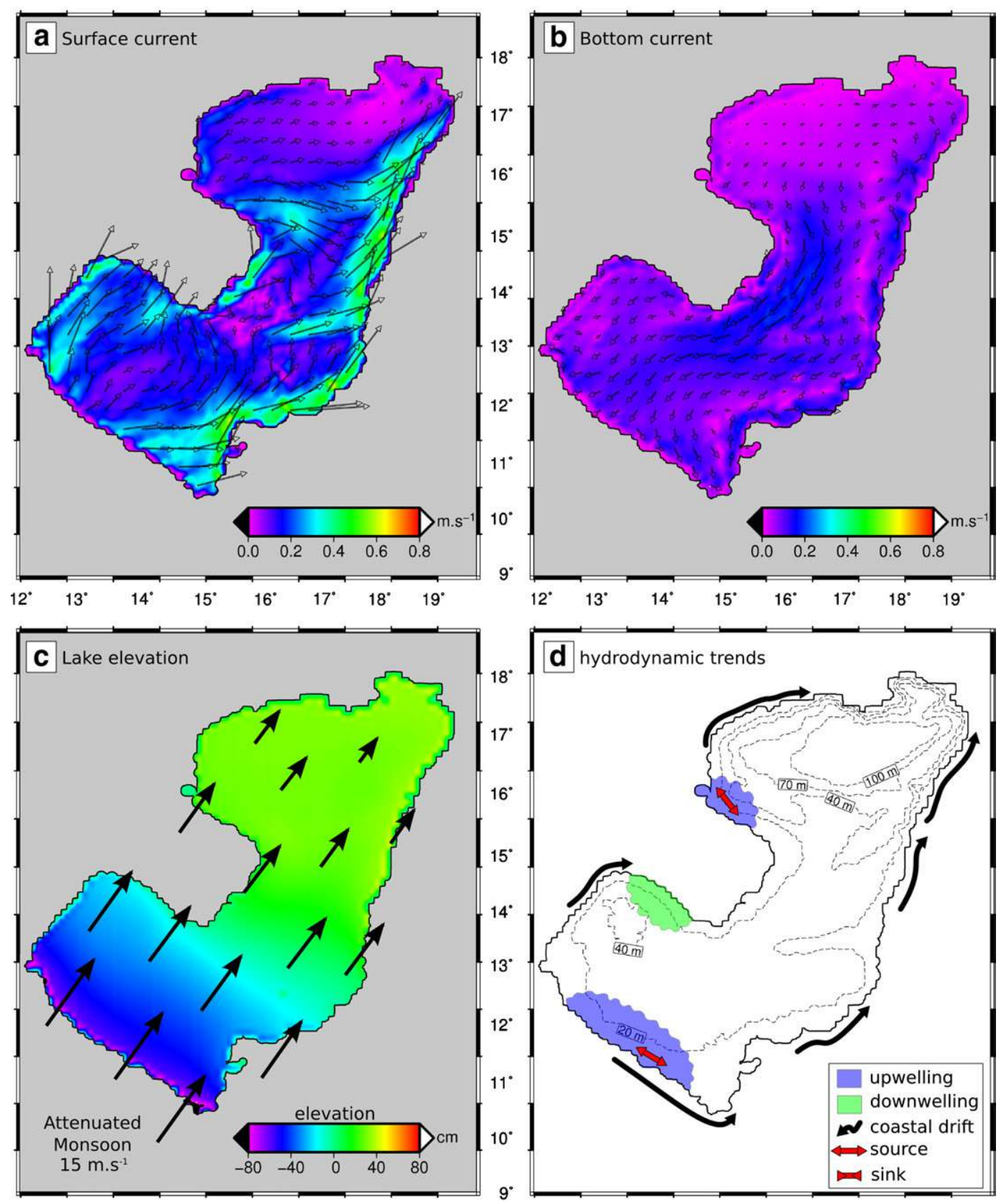

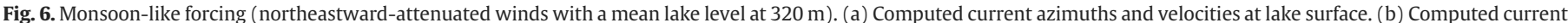

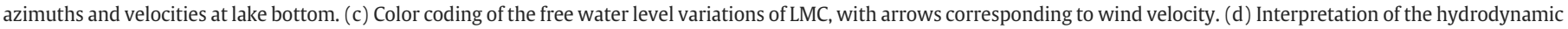
patterns.

wind forcing of $15 \mathrm{~m} / \mathrm{s}$ ). In both cases, the main surface circulation goes from the northeast to the southwest (Fig. 4a). This leads to a supply of water to the southwestern shore and results in a set-up of the water surface in this zone, while a corresponding drop (a setdown of inframetric amplitude) occurs along the northeastern edge (Fig. 4c). In response to this, the main bottom circulation, oriented northward, displays a maximum in the Bahr El Ghazal area connecting the two sub-basins.

However, the circulation in the two sub-domains remains slightly parted.

The main alongshore drifts derived from the simulations are westward along the northern coast and southward along the eastern coast. The paleo-deltas of Angamma and Goz Kerki areas are clearly under the influence of these drifts. Two westward alongshore drifts occur where the coast is strongly oblique with respect to the wind direction (mainly along the northern and southern edges of the lake).
One upwelling zone is clearly identified in the southeastern lake, North of the Chari paleo-delta, close to the modern lake Fitri. In addition, two distinct downwellings are evidenced in the northwesternmost basin and southward in the present-day basin of Lake Chad, respectively. These downwellings occur to the West, where the curvatures of the shoreline are widely open eastward. The orientation of the alongshore drifts makes the whole Kanem coast a source. The precise location of the divergence of the alongshore drifts is the easternmost Kanem. Another source is located in the northeastern end of the paleo-lake, and a possible sink is located at the southwesternmost end of LMC.

\section{Southwesterly wind forcing (Monsoon-like)}

Figure 5 displays the results for a Monsoon wind forcing of $15 \mathrm{~m} / \mathrm{s}$. Lower wind velocities result in very similar hydrodynamic patterns. 
The main surface circulation goes from the southwest to the northeast (Fig. 5a). This leads to a supply of water to the northeastern coast with a subsequent lake elevation, while a set-down (inframetric amplitude) occurs along the southwestern coast (Fig. 5c). The bottom circulation is mainly oriented from the northeast to the southwest and displays maxima located East of Kanem along Bahr el Ghazal, along the eastern coast (including Goz Kerki) and in the northwestern basin.

The main alongshore drifts derived from simulations are northeastward on both the western and eastern coasts. Along the paleocoast of Kanem that faces the southeast, the drift is oriented northeastward and results in a lakeward flow from the Kanem headland toward the eastern coast. As a consequence, a wellexpressed source occurs along the coast of the Kanem that faces the northeast. Near Goz Kerki, nearshore sedimentation appears to be controlled by a northeastward drift. The Chari paleo-delta is exposed to a northeastward drift. Along the straight southern coast, the alongshore drifts diverge from a central point corresponding to a source.

Southwesterly wind forcing with a northeastward attenuation (attenuated Monsoon-like)

Figure 6 displays the results for a Monsoon wind forcing of $15 \mathrm{~m} / \mathrm{s}$ to the southwestern coast that decreases linearly to zero to the northeast. At a latitude of $15^{\circ} \mathrm{N}$, wind forcing is still about $7 \mathrm{~m} / \mathrm{s}$. The results display many common features with those coming from a Monsoon with no attenuation but differ on some points. As before, the main surface circulation is from the southwest to the northeast (Fig. $6 a)$. This leads to a supply of water to the northeastern boundary and a subsequent lake elevation, while a set-down occurs in the southwest (Fig. 4c). The bottom circulation is mainly oriented from the northeast to the southwest and displays a maximum in the eastern Kanem in the middle of the paleolake (Fig. 6b). This maximum is of the same order as for a wind forcing with no attenuation. Along the Goz Kerki shore, the northward oriented circulation is still observed, but is slightly attenuated with respect to that displayed in Figure 5.
The main alongshore drifts are oriented northeastward on both the western and eastern coasts. Along the straight southwestern coast, the alongshore drifts diverge from a central point and form a source. Along the northern Kanem zone, an upwelling occurs near another source that is consistent but strongly attenuated with respect to the previous simulation forced by a uniform Monsoon-like wind. In this area, both surface and lake bottom mean velocities are low $(<0.20 \mathrm{~m} / \mathrm{s})$ and the flows may have not been recorded in the deposits. Along the Goz Kerki paleo-shore, currents appear as for uniform Monsoon-like forcing, clearly controlled by the northeastward drift. The Chari paleo-delta is exposed to a northward drift like for the Monsoon with no attenuation.

\section{Discussion: sedimentary constraints versus modelling results}

\section{Harmattan-like driven hydrodynamics}

Our knowledge of the paleo-wind regimes during the Holocene is of course not as accurate as for the present-day. However, a systematic comparison of all the simulations performed in this study, including those displayed in Figures 4-6, demonstrates that the global pattern of the LMC paleo-currents remains the same when the intensity of seasonal wind forcings (Harmattan-like or Monsoon-like) varies on and across the studied domain. Thus, whatever may be the variability of such forcings, the modelled hydrodynamical features are robust to first order.

The interpreted simulations presented above were compared to observed geomorphic features and, particularly, sand spits were used as morphological indicators of mean alongshore drift orientation as proposed in the literature (e.g., Short, 1999). Along the Angamma paleo-delta and the Goz Kerki paleo-coast, the curvatures of sand spits indicate that alongshore drifts were oriented towards the West and to the South respectively (Figs. 3 and 4d, and Schuster et al., 2005). This determination of mean alongshore drifts from orientation and shape of LMC fossil sand spits is confirmed by comparison with modern spits where mean alongshore drift is known (e.g., Azov Sea sand spits; Fig. 7). It clearly appears that at the time of sand spit formation, the
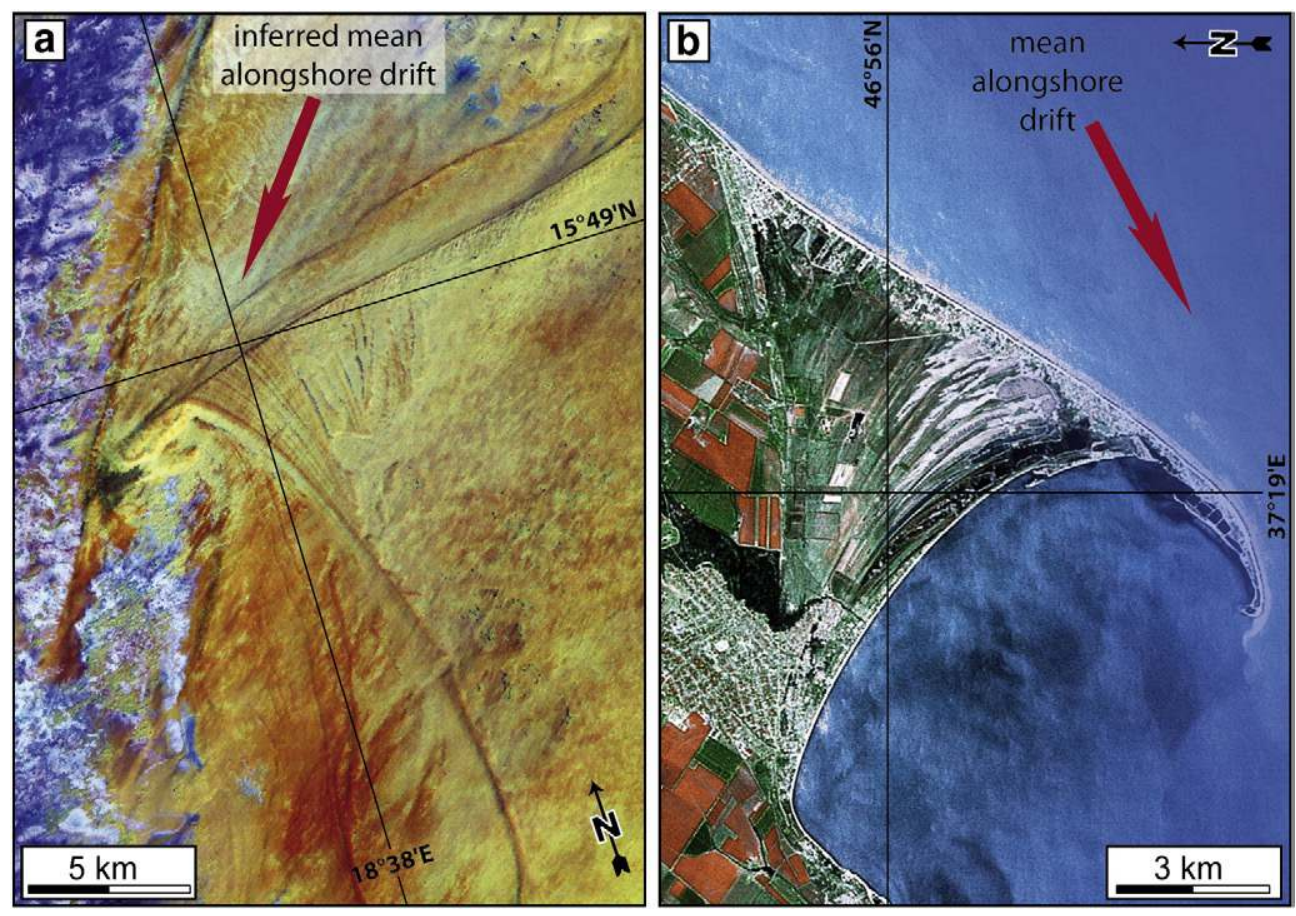

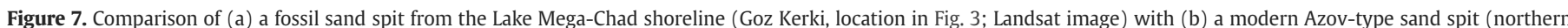

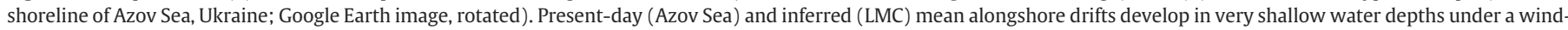

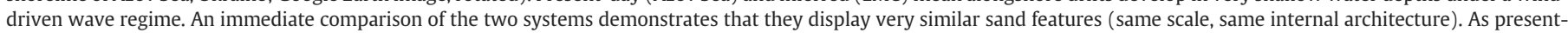
day hydrodynamics of Azov Sea is known, the comparison between (a) and (b) argues for a mean southward-directed alongshore drift along eastern LMC coastline. 
northern LMC was dominated by the influence of the Harmattan-like forcing.

\section{Monsoon contribution to hydrodynamics}

Numerical simulations forced by constant or attenuated Monsoonlike winds show for the Goz Kerki area a well-developed alongshore drift oriented toward the North (Figs. 5 and 6). This demonstrates that paleo-Monsoon winds would have been seasonally able to drive sediment transport and the shape of coastal features. However, the preserved coastal morphology appears to be clearly dominated by a southward alongshore drift (i.e., NE winds), at least in the northern sub-basin. Some sand spits (Drake and Bristow, 2006) may suggest an influence of opposite currents, but only a detailed geomorphological study could distinguish between contributions of local secondary currents (e.g., vortices) and global paleo-Monsoon wind-induced currents.

In addition, preserved features may not necessarily reflect lake hydrodynamics during the entire period of LMC highstand. Monsoonlike-driven hydrodynamics may potentially have prevailed during the early stages of LMC development but with resultant coastal features strongly reworked during later stages, which were dominated by Harmattan-like-driven sand-spit creation.

\section{Source zones}

In the Kanem zone, numerical results show constant hydrodynamic patterns both for Harmattan-like and Monsoon-like forcings (Figs. 4d, $5 \mathrm{~d}$ and $6 \mathrm{~d}$ ). For Harmattan-like wind forcing, the northeasternmost Kanem zone is clearly a source dominated by a westward transport along the northern paleo-shore and a southward drift on the eastern Kanem edge. For Monsoon-like wind forcings, the Kanem coast remains a source moderately shifted to the North. For the attenuated Monsoon-like forcing, the hydrodynamics are less significant. As a consequence, whatever may be the forcing, the simulations argue for a low sedimentation rate along the Kanem paleo-coast. Such a poor sedimentation rate does not counterbalance the permanent action of waves at the shore and the subsequent erosion of previously deposited sediments. This is in full agreement with the observations. Wave-cut terraces are environments where the effect of waves and currents is strong enough to promote coastal erosion and to prevent sediment accumulation permanently. Along the edge of the Kanem, wave-cut terraces that rework the eolian dunes field have been described at a regional scale (Fig. 3b; Schuster et al., 2005). The dunes field has been submerged partly by the paleo-lake, and some dunes have been truncated and levelled by wave erosion, but many interdunal depressions have not been filled up, perhaps because some reworked material has been carried away by alongshore drifts.

The ancient coastal zone along the erg of the Kanem is the main place where such wave-driven erosion surfaces can be observed in LMC. This particular morphology is consistent with the presence of a permanent source revealed by the simulations for both Harmattanlike and Monsoon-like wind regimes.

In the southwestern end of LMC, a well-expressed source occurs in the middle of a straight paleo-shoreline stretch (Bama ridge; Gumnior and Preusser, 2007; Fig. 2) with hydrodynamical characteristics similar to the Kanem coast that should also have promoted erosional processes under Monsoon-like conditions. However, the sediment input delivered by the Komadugu-Yobe river and other small tributaries draining the slopes of the Mandara mountains is higher than along the Kanem area. Here, sediment accretion clearly prevailed, forming the elongated Bama ridge outlining the LMC shoreline, but without any sand spits protruding as on the Goz Kerki paleo-coast. This comparison suggests that the variety of ancient coastal features observed along the LMC paleoshorelines is the result of many interactions between hydrodynam- ical circulation induced by wind forcings and other local geographic factors.

\section{Conclusion}

This paper is the first modelling effort for the determination of paleohydrodynamics in LMC during the Holocene. The aim was to compare field and remote sensing observations of paleo-lake coastal features with alongshore drifts derived from simulations of three-dimensional hydrodynamics forced by Harmattan-like and Monsoon-like winds.

We demonstrate that in the Sahara region during the African Humid Period, wind-induced coastal hydrodynamic was a major process for sediment transit over several hundreds of kilometres. Modelling results support the idea that alongshore drifts were responsible for the final basin-scale redistribution of sediment inputs by fluvial erosion and transport via reactivated river systems draining the LMC watershed.

More precisely, simulations highlight the main hydrodynamical patterns that developed at the edge of the lake under different forcings, including alongshore drifts and sediment sources and sinks. Most of the sand spits and assimilated relict coastal features observed in the Goz Kerki and the Angamma areas are consistent with the simulated alongshore drifts forced by the Harmattan-like wind. In the same way, the wave-cut terrace observed at regional scale along the northeast paleo-coast of the Kanem erg is explained by the existence of a permanent sediment source both for Harmattan-like and Monsoon-like forcings. Simulations for Monsoon-like winds (constant and attenuated) indicate also potentially significant northward alongshore drift along the Goz Kerki area, but geomorphological evidences of such drift remain questionable.

This paper shows that further work should focus on detailed morphological analysis of remote sensed data and field investigations of key features. A forthcoming activity will deal with the interpretation of those key features in terms of hydrodynamics, based on simulations taking into account more realistic constraints (fresh water inflows, paleo-winds computed from paleo-climate models, wave effect, year-long simulation including seasonal effect, land/lake surface temperature).

The present simulations represent a first step toward a more general understanding of the hydrodynamical behaviour of any closed water-body forced by alternating seasonal winds. Such results may be relevant for paleo-environmental reconstructions of older lacustrine recurrences in the Chad Basin (e.g., Duringer et al., 2007) as well as in other similar geological contexts.

\section{Acknowledgments}

We thank Claude Estournel and her team at Laboratoire d'Aérologie (CNRS UMR 5560, Université Toulouse III) to have developed the model SYMPHONIE and to spread it to the scientific community. We thank the Chadian Authorities (Ministère de l'Education Nationale de l'Enseignement Supérieur et de la Recherche, Université de N'Djamena/Département de Paléontologie, Centre National d'Appui à la Recherche), the Ministère Français de l'Education Nationale et de la Recherche (UFR SFA Université de Poitiers; Agence National de la Recherche - ANR projet 05-BLAN-0235; Centre National de la Recherche Scientifique-CNRS: EDD, SDV and ECLIPSE), Ministère des Affaires Etrangères (DCSUR, Paris and Projet FSP 2005-54 de la Coopération franco-tchadienne, Ambassade de France à N'Djaména), the Région Poitou-Charentes, the NSF program RHOI. We thank the members of the Mission Paléoanthropologique Franco-Tchadienne, G. Florent and C. Noël for administrative guidance.

\section{References}

Akima, H., 1970. A new method of interpolation and smooth curve fitting based on local procedures. J. ACM 17 (4), 589-602. 
Armitage, S.J., Drake, N.A., Stokes, S., El-Hawat, A., Salem, M.J., White, K., Turner, P., McLaren, S.J., 2007. Multiple phases of North African humidity recorded in lacustrine sediments from the Fazzan Basin, Libyan Sahara. Quaternary Geochronology 2, 181-186.

Blumberg, A. F., Mellor, G. L., 1987. A description of a three-dimensional coastal ocean circulation model. Three-Dimensional Coastal Models, Coastal and Estuarine Sciences. Ed. N.S. Heaps, American Geophysical Union Geophysical Monograph Board, 4, 1-16.

Bouffard, J., Vignudelli, S., Herrmann, M., Lyard, F., Marsaleix, P., Ménard, Y., Cipollini, P., 2008. Comparison of ocean dynamics with a regional circulation model and improved altimetry in the north-western Mediterranean. Terrestrial, Atmospheric and Oceanic Sciences 19, 1-19, doi:10.3319/TAO.2008.19.1-2.117(SA).

Bristow, C.S., Drake, N., Armitage, S., 2009. Deflation in the dustiest place on Earth: the Bodélé Depression, Chad. Geomorphology 105 (1-2), 50-58.

Burke, K., 1976. The Chad Basin: an active intra-continental basin. Tectonophysics 36, 197-206.

Capot-Rey, R., 1961. Borkou et Ounianga. Etude de géographie régionale. Mémoire de l'Institut de Recherches Sahariennes. 5, Alger, 182 p.

Conrad, G., Lappartient, J.-R., 1991. The appearance of Cardium fauna and foraminifers in the great lakes of the early quaternary period in the Algerian central Sahara desert. Journal of African Earth Sciences 12, 375-382.

Damnati, B., 2000. Holocene lake record in the Northern Hemisphere of Africa. Journal of African Earth Sciences 31, 253-262.

Denamiel, C., 2006. Three dimensional coupled modeling of swell- and wind/ buoyancy-driven currents at the midshelf scale during storm events. Phd Thesis, University of Montpellier II, 197 p.

deMenocal, P., Ortiz, J., Guilderson, T., Adkins, J., Sarnthein, M., Baker, L., Yarusinsky, M. 2000. Abrupt onset and termination of the African Humid Period: rapid climate responses to gradual insolation forcing. Quaternary Science Reviews 19, 347-361.

Drake, N., Bristow, Ch, 2006. Shorelines in the Sahara: geomorphological evidence for an enhanced Monsoon from palaeolake Megachad. The Holocene 16, 901-911.

Durand, A., 1995. Quaternary sediments and climate in the Central Sahel. African Geoscience Review 2, 323-614.

Duringer, Ph., Schuster, M., Genise, J.F., Brunet, M., Vignaud, P., 2007. New trace fossils of termites, nests and galleries, from the Chad Basin (upper Miocene and Pliocene). Palaeogeography, Palaeoclimatology, Palaeoecology 251, 323-353.

Engelstaedter, S., Tegen, I., Washington, R., 2006. North African dust emissions and transport. Earth Science Reviews 79, 73-100.

Ergenzinger, P.J., 1978. Das Gebiet des Enneri Misky im Tibesti Gebirge, Republique du Tchad. Erlauterungen zu einer Geomorphologischen Karte 1:200000. Berliner Geographischer Abhandlungen. 23, 71.

Estournel, C., Zervakis, V., Marsaleix, P., Papadopoulos, A., Auclair, F., Perivoliotis, L., Tragou, E., 2005. Dense water formation and cascading in the Gulf of Thermaikos (North Aegean) from observations and modelling. Continental Shelf Research 25, 2366-2386, doi:10.1016/j.csr.2005.08.014.

Fredsoe, J., Deigaard, R., 1995. Mechanics of coastal sediment transport, Advanced series on ocean engineering, third ed. World Scientific Publishing, Singapore. 3, $370 \mathrm{p}$.

Gasse, F., 2000. Hydrological changes in the African tropics since the Last Glacial Maximum. Quaternary Science Reviews 19, 189-211.

Ghienne, J.-F., Schuster, M., Bernard, A., Duringer, Ph., Brunet, M., 2002. The Holocene giant Lake Chad revealed by Digital Elevation Models. Quaternary International 87, 81-85.

Ghoneim, E., El-Baz, F., 2007. DEM-optical-radar data integration for palaeohydrological mapping in the northern Darfur, Sudan: implication for groundwater exploration. International Journal of Remote Sensing. 28, 5001-5018.

Guiraud, R., Maurin, J.C., 1992. Early Cretaceous rifts of Western and Central Africa: an overview. Tectonophysics 213, 153-168.

Gumnior, M., Preusser, F., 2007. Late Quaternary river development in the southwest Chad Basin: OSL dating of sediment from the Komadugu palaeofloodplain (northeast Nigeria). Journal of Quaternary Sciences 22, 709-719.

Hartley, R.W., Allen, P.A., 1994. Interior cratonic basins of Africa: relation to continental break-up and role of mantle convection. Basin Research 6, 95-113.

Hoelzmann, Ph., Keding, B., Berke, H., Kroepelin, S., Kruse, H.-J., 2001. Environmental change and archaeology: lake evolution and human occupation in the eastern Sahara during the Holocene. Palaeogeography, Palaeoclimatology, Palaeoecology $169,193-217$.

Leblanc, M., Leduc, C., Stagnitti, F., van Oevelen, P.J., Jones, C., Mofor, L.A., Razack, M., Favreau, G., 2006. Evidence for Megalake Chad, north-central Africa, during the late Quaternary from satellite data. Palaeogeography, Palaeoclimatology, Palaeoecology 230, 230-242

Lézine, A.-M., Duplessy, J.-Cl., Cazet, J.-P., 2005. West African Monsoon variability during the last deglaciation and the Holocene: evidence from fresh water algae, pollen and isotope data from core KW31, Gulf of Guinea. Palaeogeography, Palaeoclimatology, Palaeoecology. 219, 225-237.

Krist Jr., F., Schaetzl, R.J., 2001. Palaeowind (11,000 BP) directions derived from lake spits in northern Michigan. Geomorphology 38, 1-18.

Kusnir, I., Moutaye, H.A., 1997. Ressources minérales du Tchad : une revue. Journal of African Earth Sciences 24, 549-562.
Mainguet, M., Chemin, M.-C., 1990. Le Massif du Tibesti dans le système éolien du Sahara: reflexion sur la génèse du Lac Tchad. Berliner Geographische Studien 30 261-276.

Maley, J., 1977. Palaeoclimates of Central Sahara during the early Holocene. Nature 269, 573-577.

Maley, J. 1981. Etudes palynologiques dans le bassin du Tchad et Paléoclimatologie de l'Afrique nord tropicale de 30000 ans à l'époque actuelle, ed. ORSTOM, Paris. 129 $586 \mathrm{p}$

Marsaleix, P., Auclair, F., Floor, J.W., Herrmann, M.J., Estournel, C., Pairaud, I., Ulses, C., 2008. Energy conservation issues in sigma-coordinate free-surface ocean models. Ocean Modelling 20, 61-89, doi:10.1016/j.ocemod.2007.07.005.

Mellor, G., 2003. The three-dimensional current and surface wave equations. Journal of Physical Oceanography 33, 1978-1989.

Olivry, J.C., Chouret, A., Lemoalle, J., Bricquet, J.P., 1996. Hydrologie du lac Tchad. ORSTOM Paris, 266 p.

Pachur, H.J., Rottinger, F., 1997. Evidence for large extended palaeolake in the eastern Sahara as revealed by spaceborne radar lab images. Remote Sensing of Environment 61, 437.

Pachur, H.J., Hoelzmann, P., 2000. Late Quaternary palaeoecology and palaeoclimates of the eastern Sahara. Journal of African Earth Sciences 30, 929-939.

Petit-Maire, N., Casta, L., Delibrias, G., Gaven, Ch., Testud, A.-M., 1980. Preliminary Data on Quaternary Palaeolacustrine Deposits in the Wadi ash Shati Area, Libya. In: Salem, M.J., Busrewil, M.T. (Eds.), The Geology of Libya III. Academic Press, London, pp. 797-807.

Petit-Maire, N., Riser, J., 1983. Sahara ou Sahel? Quaternaire récent du Bassin de Taoudenni (Mali). CNRS, Marseille, $473 \mathrm{p}$.

Pias, J., Guichard, E., 1957. Origine et conséquences de l'existence d'un cordon sableux dans la partie sud-ouest de la cuvette tchadienne. Compte Rendu Académie des Sciences de Paris 244, 791-793.

Rabus, B., Eineder, M., Roth, A., Bamler, A., 2003. The shuttle radar topography missiona new class of digital elevation models acquired by spaceborne radar. ISPRS Journal of Photogrammetry and Remote Sensing 57, 241-262.

Shchepetkin, A.F., Mc Williams, J.C., 2005. The regional oceanic modeling system (roms): A split-explicit, free surface, topography-following-coordinate oceanic model. Ocean Modelling 9, 347-404.

Schneider, J.L., 1967. Evolution du dernier lacustre et peuplement préhistorique aux Pays Bas du Tchad. Bulletin ASEQUA 14/15, 203-215.

Schuster, M., 2002. Sédimentologie et paléoécologie des series à vertébrés du paléolac Tchad depuis le Miocène supérieur. PhD thesis, University of Strasbourg, 152 p.

Schuster, M., Duringer, Ph., Ghienne, J.-F., Bernard, A., Brunet, M., Vignaud, P., Mackaye, H.T., 2001. The Holocene Lake Mega-Chad: extension, dynamic and palaeoenvironmental implications since upper Miocene. European Union of Geosciences XI, Strasbourg, France, 8-12 April 2001. Abstract book and CDROM. 177.

Schuster, M., Duringer, Ph., Ghienne, J.-F., Vignaud, P., Beauvilain, A., Mackaye, H.T., Brunet, M., 2003. Coastal conglomerate around the Hadjer el Khamis inselbergs (western Chad, Central Africa): new evidence for Lake Mega-Chad episodes. Earth Surface Processes and Landforms 28, 1059-1069.

Schuster, M., Roquin, C., Brunet, M., Duringer, Ph., Fontugne, M., Mackaye, H.T., Vignaud P., Ghienne, J.-F., 2005. Highlighting Holocene Lake Mega-Chad paleoshorelines from space. Quaternary Science Reviews 24, 1821-1827.

Sepulchre, P., Schuster, M., Ramstein, G., Krinner, G., Girard, J.-F., Fluteau, F., Vignaud, P., Brunet, M., 2008. Simulating the Holocene Lake Mega Chad with an AGCM coupled with a lake model: a preliminary approach. Global and Planetary Change 61, 41-48.

Servant, M., Servant-Vildary, S., 1980. L'environnement Quaternaire du Bassin du Tchad. In: Williams, M.A.J., Faure, H. (Eds.), The Sahara and the Nile. Balkema, Rotterdam, pp. 133-162.

Short, A.D., 1999. Handbook of beach shoreface and morphodynamics. Wiley and Sons, $380 \mathrm{p}$.

Ulses, C., Grenz, C., Marsaleix, P., Schaaff, E., Estournel, C., Meulé, S., Pinazo, C., 2005. Circulation in a semi enclosed bay under the influence of strong fresh water input. Journal of Marine Systems 56, 113-132, doi:10.1016/j.jmarsys.2005.02.001.

Ulses, C., Estournel, C., Puig, P., Durrieu de Madron, X., Marsaleix, P., 2008. Dense shelf water cascading in the north-western Mediterranean during the cold winter 2005 Quantification of the export through the Gulf of Lion and the Catalan margin. Geophysical Research Letters 35, L07610, doi:10.1029/2008GL033257.

Vignaud, P., Duringer, Ph., Mackaye, H.T., Likius, A., Blondel, C., Boisserie, J.-R., de Bonis L., Eisenmann, V., Etienne, M., Geraads, D., Guy, F., Lehmann, Th., Lihoreau, F., LopezMartinez, N., Mourer-Chauviré, C., Otero, O., Rage, J.-Cl., Schuster, M., Viriot, L., Zazzo, A., Brunet, M., 2002. Geology and palaeontology of the Upper Miocene Toros-Menalla hominid locality, Chad. Nature 418, 152-155.

Warren, A., Chappell, A., Todd, M. C., Bristow, C., Drake, N., Engelstaedter, S., Martins, V., M'bainayel, S., Washington, R., 2007. Dust-raising in the dustiest place on earth. Geomorphology 92, 1-2, 25-37.

Wessel, P., Smith, W.H.F., 1998. New, improved version of the Generic Mapping Tools Released. EOS Trans, ed. American Geophysical Union 79, 579.

Wolf, J. P., 1964. Carte géologique de la République du Tchad au 1/15000000ème, ed. BRGM, Paris. 